\title{
PENGARUH SELF ASSESMENT SYSTEM, SURAT TAGIHAN PAJAK DAN RESTITUSI PAJAK PERTAMBAHAN NILAI TERHADAP PENERIMAAN PAJAK PERTAMBAHAN NILAI (PPN) (Studi Kasus Pada Kantor Pelayanan Pajak Pratama Cibinong Tahun 2014-2016)
}

${ }^{1}$ Saesar Ayu Pratiwi, ${ }^{2}$ Elly Suryani, ${ }^{3}$ Kurnia

1,Prodi S1 Akuntansi, Fakultas Ekonomi dan Bisnis, Universitas Telkom e-mail: 1ayu31razi17@gmail.com,

2,Prodi S1 Akuntansi, Fakultas Ekonomi dan Bisnis, Universitas Telkom

²ellysuryani@telkomuniversity.ac.id

3..Prodi S1 Akuntansi, Fakultas Ekonomi dan Bisnis, Universitas Telkom 33akukurnia@telkomuniversity.ac.id.

\section{Abstract}

This study aims to examine the influence of Self Assessment System, Tax Refining Letter, and VAT Refund of Value Added Tax at Primary Tax Office Cibinong during 2014-2016. The data used in this research is the type of secondary data year 2014-2016.

The population in this study is the data of all types of taxes at the Tax Office Pratama Cibinong. The sample selection technique used is purposive sampling. Data analysis method in this research is multiple linear regression analysis using SPSS version 23.

Based on the results of the study, simultaneously Self Assessment System, Tax Refining Letterss, and VAT Restitution have a significant effect on VAT revenue. While partially, Self Assessment System has a positive and significant effect on VAT revenue, Tax Refining Letters has no significant effect on VAT revenue, and VAT refund has negative and significant effect on VAT revenue

Keywords: Self Assesment System, STP, VAT Restitution, Value Added Tax Revenue

1. Pendahuluan

Pajak Pertambahan Nilai (PPN) adalah pajak konsumsi atas barang dan jasa di dalam daerah pabean yang dikenakan secara bertingkat di setiap jalur produksi dan distribusi. PPN dibebankan kepada wajib pajak orang pribadi atau 
wajib pajak badan selama menggunakan barang dan jasa oleh sebab itu PPN memiliki peranan yang strategis dan signifikan dalam penerimaan negara. Namun sepanjang tahun 2014, 2015, dan 2016 penerimaan PPN belum mencapai target anggaran. Secara umum melambatnya pertumbuhan PPN DN tahun 2014 disebabkan oleh perekonomian di Indonesia yang mengalami tekanan akibat menguatnya kondisi perekonomian di AS. Catatan Kemenkeu juga mencatat realisasi PPN tahun 2015 sebesar Rp 423,7 triliun dan pada 2016 sebesar Rp 410,5 triliun dengan realisasi sementara itu, maka kinerja PPN tahun lalu turun $3,21 \%$ dibanding dengan tahun sebelumnya.

Penerimaan PPN sangat dipengaruhi oleh kesadaran PKP dalam menyetorkan dan melaporkan PPN yang terutang karena secara langsung PKP merupakan pemikul beban pembayaran PPN dan penanggungjawab penyetoran PPN ke kas negara, melunasi tagihan pajak yang diterbitkan oleh DJP serta mengklaim pengembalian PPN yang menjadi hak PKP, maka dari itu penelitian ini menggunakan variabel Self Assessment System, Surat Tagihan Pajak dan Restitusi PPN. Penulis melakukan penelitian di KPP Pratama Cibinong karena daerah cibinong terdapat banyak industri yang sedang berkembang sehingga potensi PKP sangat tinggi.

\section{Dasar Teori dan Metodologi}

\subsection{Pajak Pertambahan Nilai}

Menurut UU No 42 Tahun 2009 PPN adalah pajak konsumsi yang dikenakan secara bertingkat di setiap jalur produksi dan distribusi. PPN dikenakan dan disetorkan oleh pengusaha atau perusahaan yang telah dikukuhkan sebagai Pengusaha Kena Pajak (PKP). Sejak 1 Juli 2016, PKP seIndonesia wajib membuat e-faktur atau faktur pajak elektronik untuk menghindari penerbitan faktur pajak fiktif untuk pengenaan PPN kepada lawan transaksinya.

\subsection{Self Assesment System}

Self Assesment System adalah Adalah sistem pemungutan pajak yang memberi wewenang kepada wajib pajak dalam menentukan sendiri jumlah pajak yang terutang setiap tahunnya sesuai dengan peraturan perundang-undangan perpajakan yang berlaku. Dalam sistem ini, insiatif serta kegiatan menghitung dan memungut pajak sepenuhnya berada di tangan wajib pajak. Self Assesment System pada penelitian ini diukur melalui :

Self Assesment System = Jumlah surat setoran pajak PPN yang disetorkan oleh PKP, Kantor Pelayanan Pajak Pratama Cibinong per bulan dari tahun 2014 sampai dengan 2016.

\subsection{Surat Tagihan Pajak}

Menurut Siti Resmi (2017:51) Surat Tagihan Pajak adalah surat untuk melakukan tagihan pajak dan atau sanksi administrasi berupa bungan dan atau denda. Surat Tagihan Pajak di terbitkan apabila: (1) Pengusaha yang telah dikukuhkan sebagai Pengusaha Kena Pajak yang tidak mengisi faktur pajak secara lengkap (2) Pengusaha yang tidak dikukuhkan sebagai PKP tetapi membuat faktur pajak (3) Pengusaha yang dikenakan pajak berdasarkan UU 
PPN 1984 tetapi tidak melaporkan kegiatan usahanya untuk dikukuhkan sebagai PKP. STP PPN pada penelitian ini diukur melalui :

Surat Tagihan Pajak = Jumlah surat tagihan pajak yang diterbitkan untuk PKP dari Kantor Pelayanan Pajak Pratama Cibinong per bulan dari tahun 2014 sampai dengan

\subsection{Restitusi PPN} 2016.

Menurut Djuanda dan Lubis $(2011 ; 121)$ Kelebihan pembayaran Pajak Pertambahan Nilai terjadi karena jumlah pajak masukan yang dibayar lebih besar dari pada jumlah Pajak Keluaran yang dipungut dalam suatu Masa Pajak. Restitusi PPN pada penelitian ini diukur melalui :

Restitusi PPN = Jumlah restitusi PPN per bulan dari tahun 2014 sampai dengan 2016 pada Kantor Pelayanan Pajak Pratama Cibinong

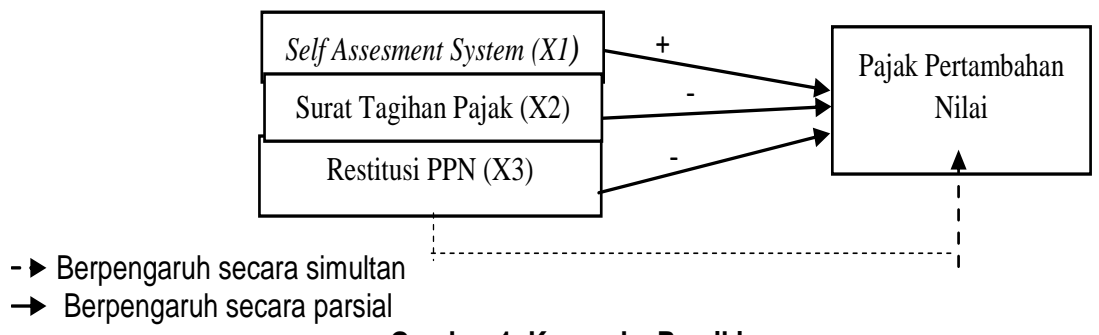

Gambar 1. Kerangka Pemikiran

\section{Metodologi}

Penelitian ini menggunakan dua jenis variabel, variabel bebas yaitu Self Assesment System, Surat Tagihan Pajak, Restitusi PPN dan variabel terikat yaitu Penerimaan Pajak Pertambahan Nilai. Tujuan dari penelitian ini adalah untuk mengetahui pengaruh Self Assesment System, Surat Tagihan Pajak, dan Restitusi PPN terhadap Penerimaan PPN pada KPP Pratama Cibinong baik secara simultan maupun parsial.

Data semua jenis pajak pada KPP Pratama Cibinong tahun 2014-2016 dipilih sebagai populasi penelitian. Teknik purposive sampling digunakan untuk pengambilan sampel dan waktu pelaksanaan berdasarkan runtutan waktu (time series). Model analisis dalam penelitian ini adalah regresi linear berganda dengan menggunakan software SPSS versi 23.

\section{Hasil Penelitian dan Pembahasan}

\subsection{Statistik Deskriptif}

Hasil analisis deskriptif variabel operasional adalah sebagai berikut:

Tabel.1 Hasil Pengujian Statistik Deskriptif

\begin{tabular}{|c|c|c|c|c|c|}
\hline & $\mathrm{N}$ & Minimum & Maximum & Mean & Std.Deviation \\
\hline Self & 3 & 2.584 & 9.070 & 4.221 & 1.464 \\
\hline \multicolumn{3}{|c|}{ (2) UJama } & \multicolumn{3}{|c|}{ Saesar Ayu Pratiwi, Elly Suryani, } \\
\hline
\end{tabular}




\section{ISSN}

\begin{tabular}{|l|r|r|r|r|r|}
\hline $\begin{array}{l}\text { Assesment } \\
\text { System } \\
\text { (X1) }\end{array}$ & 6 & & & & \\
Surat & 3 & & & & \\
Tagihan & 6 & 5 & 823 & 230 & 204 \\
Pajak (X2) & & & & & \\
Restitusi & 3 & 4.256 .557 & 11.700 .503 .88 & 2.881 .981 .62 & 2.961 .659 .39 \\
PPN (X3) & 6 & 5 & 8 & 8 \\
Penerimaa & 3 & 42.259 .977 .7 & 160.383 .898 .0 & 70.300 .959 .0 & 26.585 .908 .2 \\
n Pajak & 6 & 93 & 23 & 33 & 49 \\
Pertambah & & & & & \\
an Nilai (Y) & & & & & \\
Valid N & 3 & & & & \\
(listwise) & 6 & & & & \\
\hline
\end{tabular}

Sumber: Data yang telah diolah,2018.

Pada Tabel.1 menggambarkan deskriptif statistik variabel penelitian di KPP Pratama Cibinong tahun 2014-2016. Variabel Self Assesment System $\left(\mathrm{X}_{1}\right)$ yang diukur melalui jumlah lembar SSP PPN dengan jumlah sampel sebanyak 36 bulan memiliki nilai rata-rata (mean) sebesar 4.221 lembar dengan nilai standar deviasi sebesar 1.464. Pada Self Assesment System memiliki nilai rata-rata (mean) lebih besar dibanding dengan nilai standar deviasi hal ini menggambarkan bahwa data pada variabel Self Assesment System tidak menyebar ataupun bervariasi. Self Assesment System memiliki nilai terendah ( $\min$ ) sebesar 2.584 lembar, dan nilai tertinggi ( $\max$ ) sebesar 9.070 lembar.

Variabel Surat Tagihan Pajak $\left(\mathrm{X}_{2}\right)$ yang diukur melalui jumlah lembar STP PPN dengan jumlah sampel sebanyak 36 bulan memiliki nilai rata-rata (mean) sebesar 230 lembar dengan standar deviasi sebesar 204 lembar. Pada Surat Tagihan Pajak memiliki nilai rata-rata (mean) lebih besar dibanding dengan nilai standar deviasi hal ini menggambarkan bahwa data pada variabel Surat Tagihan Pajak tidak menyebar ataupun bervariasi. Surat Tagihan Pajak memiliki nilai terendah ( $\min$ ) sebesar 5 lembar, dan nilai tertinggi (max) sebesar 823 lembar.

Variabel Restitusi Pajak PPN $\left(\mathrm{X}_{3}\right)$ dengan jumlah sampel sebanyak 36 bulan memiliki nilai rata-rata (mean) sebesar Rp 2.881.981.628 dengan standar deviasi sebesar Rp 2.961.659.398. Pada Restitusi Pajak PPN memiliki nilai ratarata (mean) lebih kecil dibanding dengan nilai standar deviasi hal ini menggambarkan bahwa data pada variabel Restitusi Pajak PPN menyebar dan bervariasi. Restitusi Pajak PPN memiliki nilai terendah (min) sebesar Rp 4.256.557 dan nilai tertinggi (max) sebesar Rp 11.700.503.885.

Variabel Pajak Pertambahan Nilai $(\mathrm{Y})$ dengan jumlah sampel sebanyak 36 bulan memiliki nilai rata-rata (mean) sebesar Rp 70.300.959.033 dengan standar deviasi sebesar Rp 26.585.908.249. Pada Pajak Pertambahan Nilai memiliki nilai rata-rata (mean) lebih besar dibanding dengan nilai standar deviasi hal ini menggambarkan bahwa data pada variabel Pajak Pertambahan Nilai tidak menyebar ataupun bervariasi. Pajak Pertambahan Nilai memiliki nilai terendah ( $\min$ ) sebesar $\mathrm{Rp}$ 42.259.977.793, dan nilai tertinggi (max) sebesar Rp 160.383.898.023. 


\subsection{Uji Asumsi Klasik}

\subsubsection{Uji Normalitas}

Tabel.2 One Sample Kolmogorov-Smirnov Test

\begin{tabular}{|ll|r|}
\hline & & $\begin{array}{r}\text { Unstandardize } \\
\text { d Residual }\end{array}$ \\
\hline $\mathrm{N}$ & & 36 \\
Normal Parameters & Mean & .0000000 \\
& Std. Deviation & .15100678 \\
Most Extreme Differences & Absolute & .133 \\
& Positive & .133 \\
& Negative & -.100 \\
Test Statistik & & .133 \\
Asymp. Sig. (2-tailed) & & $.109^{\mathrm{c}}$ \\
\hline
\end{tabular}

Sumber : Ouput SPSS, 2018.

Tabel.2 uji normalitas diatas dapat diketahui bahwa nilai sig sebesar 0,109 . Karena nilai Sig $(0,109)>0,05$ maka data di atas dapat digunakan karena variabel residu berdistribusi normal. Dengan demikian $\mathrm{H}_{0}$ diterima,yang berarti model regresi yang digunakan normal sehingga data dapat digunakan untuk analisis selanjutnya.

\subsubsection{Uji Autokorelasi}

\begin{tabular}{|l|r|}
\hline \multicolumn{2}{|c|}{ Tabel.3 Uji Durbin-Watson } \\
\hline 1 & \multicolumn{2}{|c|}{ Durbin-Watson } \\
\hline & \\
\hline
\end{tabular}

Sumber : Hasil output SPSS 23, 2018.

Berdasarkan tabel diatas diperoleh nilai Durbin-Watson sebesar 1,702. Karena nilai dL $(1,2953) \leq \mathrm{DW}(1,702) \leq 4-\mathrm{dU}(2,346)$, maka dapat disimpulkan pada analisis regresi tidak ada autokorelasi atau tidak terdapat autokorelasi positif maupun negatif pada data yang diuji.

\subsubsection{Uji Heteroskedasitas}

Tabel.4 Uji Heteroskedastisitas

\begin{tabular}{|lll|r|}
\hline & & & $\begin{array}{c}\text { Unstandardize } \\
\text { d Residual }\end{array}$ \\
\hline Spearman's rho & Self Assesment System & Correlation Coefficient & -.048 \\
& $(\mathrm{X} 1)$ & Sig. (2-tailed) & .782 \\
& & $\mathrm{~N}$ & 36 \\
\cline { 2 - 4 } & Surat Tagihan Pajak (X2) & Correlation Coefficient & -.058 \\
& & Sig. (2-tailed) & .737 \\
\hline
\end{tabular}


ISSN

2460-030X

\begin{tabular}{|ll|r|}
\hline & N & 36 \\
\cline { 2 - 3 } & & -.212 \\
& & .214 \\
& Costitusi Pajak PPN (X3) & 36 \\
& Sig. (2-tailed) & 36 . \\
\end{tabular}

Sumber : Hasil output SPSS 23, 2018.

Dari output di atas dapat dilihat bahwa terdapat korelasi yang tidak signifikan. Hal ini dilihat dari nilai p-value (Sig) yang lebih besar dari 0,05. Nilai $p$ value (Sig) Self Assesment System $\left(X_{1}\right)$ sebesar 0,782 >0,05, nilai p-value (Sig) Surat Tagihan Pajak $\left(X_{2}\right)$ sebesar 0,737 $>0,05$, nilai $p$-value (Sig) Restitusi PPN $\left(X_{3}\right)$ sebesar $0,214>0,05$. Sehingga dapat disimpulkan pada analisis regresi tidak terjadi heteroskedastisitas dengan kata lain tidak terjadi kesamaan varians antar variabel bebas.

\subsubsection{Uji Multikolinearitas}

Tabel.5 Uji Multikolinearitas

\begin{tabular}{|ll|r|c|}
\hline \multirow{2}{*}{ Model } & \multicolumn{2}{c|}{ Collinearity Statistiks } \\
\cline { 3 - 4 } & & Tolerance & \multicolumn{1}{c|}{ VIF } \\
\hline 1 & Self Assesment Sytem (X1) & .798 & 1.254 \\
& Surat Tagihan Pajak (X2) & .795 & 1.258 \\
& Restitusi Pajak PPN (X3) & .984 & 1.016 \\
\hline
\end{tabular}

Sumber : Output SPSS 23, 2018.

Nilai variance inflator factor (VIF) adalah faktor inflasi penyimpangan baku kuadrat. Jika nilai VIF $<10,00$ maka tidak terjadi multikolonieritas, dapat dilihat pada Tabel.5 nilai VIF. Nilai VIF Self Assesment System sebesar 1,254<10, nilai VIF Surat Tagihan Pajak 1,258 < 10, nilai VIF Restitusi Pajak PPN sebesar $1,016<10$ dengan ini maka dapat disimpulkan bahwa tidak terdapat multikolinearitas dalam data.

\subsection{Menguji Regresi Linear Berganda}

Tabel.6 Analisis Regresi Linear Berganda

\begin{tabular}{|c|c|c|c|c|c|c|}
\hline \multirow[b]{2}{*}{ Model } & \multicolumn{2}{|c|}{$\begin{array}{l}\text { Unstandardized } \\
\text { Coefficients }\end{array}$} & \multirow{2}{*}{$\begin{array}{c}\text { Standardized } \\
\text { Coefficients } \\
\text { Beta }\end{array}$} & \multirow[b]{2}{*}{$\mathrm{t}$} & \multirow[b]{2}{*}{ Sig. } & \multirow{2}{*}{$\begin{array}{l}\text { Correlations } \\
\text { Zero-order }\end{array}$} \\
\hline & B & $\begin{array}{l}\text { Std. } \\
\text { Error }\end{array}$ & & & & \\
\hline 1 (Constant) & 18.091 & .905 & & 19.995 & .000 & \\
\hline
\end{tabular}




\begin{tabular}{|c|c|c|c|c|c|c|}
\hline $\begin{array}{l}\text { Self } \\
\text { Assesment } \\
\text { System (X1) }\end{array}$ & .910 & 106 & .838 & 8.620 & .000. & .848 \\
\hline $\begin{array}{l}\text { Surat Tagihan } \\
\text { Pajak (X2) }\end{array}$ & -.005 & .025 & -.020 & -.202 & 842 & .378 \\
\hline $\begin{array}{l}\text { Restitusi Pajak } \\
\text { PPN (X3) }\end{array}$ & -.034 & .015 & - 200 & -2.281 & .029 & -.279 \\
\hline
\end{tabular}

Sumber : Output SPSS 23, 2018.

Berdasarkan hasil perhitungan pada Tabel.6 di atas, diperoleh bentuk persamaan regresi linier berganda sebagai berikut :

$$
Y=18,091+0,910 X_{1}-0,005 X_{2}-0,034 X_{3}
$$

$Y=$ Pajak Pertambahan Nilai

$\mathrm{X}_{1}=$ Self Assesment System

$\mathrm{X}_{2}=$ Surat Tagihan Pajak

$\mathrm{X}_{3}=$ Restitusi PPN

$\mathrm{e}=$ Error Term

Persamaan regresi data panel dapat diartikan sebagai berikut:

a. Nilai konstanta sebesar 18,091 menunjukan bahwa apabila variabel independen pada regresi yaitu Self Assesment System, Surat Tagihan Pajak, dan Restitusi PPN bernilai nol, maka nilai Penerimaan PPN yaitu sebesar 18,091satuan.

b. Koefisien regresi Self Assesment System sebesar + 0,910 menunjukkan bahwa setiap terjadinya peningkatan Self Assesment System sebesar satu satuan dengan asumsi variabel lain bernilai nol, maka Penerimaan PPN akan mengalami kenaikan sebesar 0,910 satuan.

c. Koefisien regresi Surat Tagihan Pajak sebesar - 0,005 menunjukkan bahwa setiap terjadinya peningkatan Surat Tagihan Pajak sebesar satu satuan dengan asumsi variabel lain bernilai nol, maka Penerimaan PPN akan mengalami penurunan sebesar 0,005 satuan.

d. Koefisien regresi Restitusi PPN sebesar - 0,034 menunjukkan bahwa setiap terjadinya peningkatan Restitusi PPN sebesar satu satuan dengan asumsi variabel lain bernilai nol, maka Penerimaan PPN perusahaan akan mengalami penurunan sebesar 0,034 satuan. 
ISSN

Jurnal Akuntansi Bisnis dan Ekonomi

2460-030X

Volume 4 No. 2, September 2018

\subsubsection{Koefisien Determinasi}

Tabel.7 Model Summary

\begin{tabular}{|l|r|r|r|r|}
\hline Model & $\mathrm{R}$ & R Square & \multicolumn{1}{|c|}{$\begin{array}{c}\text { Adjusted R } \\
\text { Square }\end{array}$} & $\begin{array}{c}\text { Std. Error of the } \\
\text { Estimate }\end{array}$ \\
\hline 1 & $.871^{\mathrm{a}}$ & .759 & .736 & .16027 \\
\hline
\end{tabular}

Sumber : Output SPSS 23, 2018.

Terlihat pada Tabel.7 diatas nilai Adjusted $R$ Square sebesar 0,736 atau $73,6 \%$. Hal ini menggambarankan bahwa variabel Self Assesment System $\left(X_{1}\right)$, Surat Tagihan Pajak $\left(X_{2}\right)$ dan Restitusi PPN $\left(X_{3}\right)$ memberikan pengaruh sebesar 73,6\% terhadap Penerimaan Pajak Pertambahan Nilai (Y). Sedangkan sisanya sebesar $26,4 \%$ merupakan kontribusi variabel lain selain Self Assesment System $\left(\mathrm{X}_{1}\right)$, Surat Tagihan Pajak $\left(\mathrm{X}_{2}\right)$ dan Restitusi PPN $\left(\mathrm{X}_{3}\right)$.

\subsubsection{Uji Hipotesis Secara Simultan (Uji F)}

Tabel.8 Hipotesisis secara Simultan (Uji F)

\begin{tabular}{|c|c|c|c|c|c|}
\hline F hitung & Df & F Tabel & Sig & Keterangan & Kesimpulan \\
\hline \multirow{2}{*}{33,573} & $\mathrm{df} 1=3$ & 2,901 & 0,000 & Ho ditolak & $\begin{array}{c}\text { Ada pengaruh } \\
\text { (Signifikan) }\end{array}$ \\
\cline { 2 - 2 } & $\mathrm{df} 2=32$ & 2,001 &
\end{tabular}

Sumber : Data diolah kembali, 2018.

Dari Tabel.8 diatas, diperoleh nilai $\mathrm{F}$ hitung sebesar 33,573. Karena nilai $\mathrm{F}$ hitung 33,573 > F tabel 2,901, maka Ho ditolak. Dengan demikian dapat disimpulkan bahwa secara simultan terdapat pengaruh yang signifikan dari Self Assesment System $\left(\mathrm{X}_{1}\right)$, Surat Tagihan Pajak $\left(\mathrm{X}_{2}\right)$ dan Restitusi PPN $\left(\mathrm{X}_{3}\right)$ terhadap Penerimaan Pajak Pertambahan Nilai $(\mathrm{Y})$.

\subsubsection{Uji Hipotesis Secara Parsial (Uji t)}

Tabel.9 Uji Hipotesis secara Parsial (Uji t)

\begin{tabular}{|c|c|c|c|c|c|c|}
\hline Variabel & $\mathbf{t}$ hitung & Df & $\mathbf{t}$ Tabel & Sig & Keterangan & Kesimpulan \\
\hline X1 & 8,620 & 32 & 2,037 & 0,000 & Ho ditolak & Signifikan \\
\hline X2 & $-0,202$ & 32 & 2,037 & 0,842 & Ho diterima & Tidak Signifikan \\
\hline X3 & $-2,281$ & 32 & 2,037 & 0,029 & Ho ditolak & Signifikan \\
\hline
\end{tabular}

Sumber : Data diolah kembali, 2018.

Berdasarkan tabel diatas maka dapat simpulkan bahwa :

1. Variabel $X_{1}$ memiliki nilai $t$ hitung lebih besar dari nilai $t$ Tabel. Karena nilai t hitung $|8,620|>\mathrm{t}$ tabel $|2,037|$, maka $\mathrm{Ho}_{1}$ ditolak. Oleh karena itu dapat disimpulkan bahwa secara parsial terdapat pengaruh signifikan 
dari Self Assesment System $\left(\mathrm{X}_{1}\right)$ terhadap Penerimaan Pajak Pertambahan Nilai $(Y)$.

2. Variabel $X_{2}$ memiliki nilai $t$ hitung lebih besar dari nilai $t$ Tabel. Karena nilai t hitung $|-0,202|<\mathrm{t}$ tabel $|2,037|$, maka $\mathrm{Ho}_{2}$ diterima. Oleh karena itu dapat disimpulkan bahwa secara parsial tidak terdapat pengaruh signifikan dari Surat Tagihan Pajak $\left(\mathrm{X}_{2}\right)$ terhadap Penerimaan Pajak Pertambahan Nilai (Y).

3. bahwa Variabel $X_{3}$ memiliki nilai $t$ hitung lebih besar dari nilai $t$ tabel. Karena nilai t hitung $|-2,281|>t$ tabel $|2,037|$, maka $\mathrm{Ho}_{3}$ ditolak. Oleh karena itu dapat disimpulkan bahwa secara parsial terdapat pengaruh signifikan dari Restitusi PPN $\left(\mathrm{X}_{3}\right)$ terhadap Penerimaan Pajak Pertambahan Nilai (Y).

\section{Kesimpulan dan Saran}

\subsection{Kesimpulan}

Penelitian ini menunjukkan bahwa variabel Self Assesment System, Surat Tagihan Pajak, dan Restitusi PPN berpengaruh secara simultan terhadap Penerimaan PPN pada KPP Pratama Cibinong periode 2014-2016. Nilai Adjusted RSquare yang diperoleh pada penelitian ini sebesar 0,736 hal ini menggambarkan variabel Self Assesment System, Surat Tagihan Pajak, dan Restitusi PPN memberi pengaruh $73,6 \%$ sedangkan sisanya $26,4 \%$ dipengaruhi oleh variabel lain diluar penelitian. Secara parsial, pengaruh variabel bebas terhadap variabel terikat adalah sebagai berikut:

1. Self Assesment System berpengaruh positif dan signifikan terhadap Penerimaan PPN pada KPP Pratama Cibinong periode 2014-2016.

2. Surat Tagihan Pajak tidak memiliki pengaruh signifikan terhadap Penerimaan PPN pada KPP Pratama Cibinong periode 2014-2016.

3. Restitusi PPN berpengaruh negatif terhadap Penerimaan PPN pada KPP Pratama Cibinong periode 2014-2016.

\subsection{Saran}

Berdasarkan kesimpulan yang ada, maka peneliti memberikan saran adalah sebagai berikut:

\section{Aspek Teoritis}

Berdasarkan hasil penelitian, penulis mencoba untuk mengetahui faktorfaktor yang mempengaruhi Penerimaan Pajak Pertambahan nilai pada KPP Cibinong periode 2014-2016. Keterbatasan waktu penelitian menjadi penyebab hanya dipilihnya beberapa variabel dan periode objek penelitian. Oleh karena itu, berdasarkan hasil penelitian penulis ingin memberikan saran kepada para peneliti selanjutnya yaitu menambah variabel penelitian dan memperluas objek penelitian misalnya penelitian dilakukan pada Kantor Wilayah Direktorat Jendral Pajak Jawa Barat II yang menampung 13 KPP Pratama, dan juga lebih memperluas tahun penelitian.

\section{Aspek Praktis}

Berdasarkan hasil penelitian ini Self Assesment System, Surat Tagihan Pajak, dan Restitusi PPN mempunyai pengaruh signifikan terhadap Penerimaan PPN Sehingga peneliti mengharapkan bahwa penelitian ini dapat menjadi bahan 
masukan dan evaluasi kepada pemerintah agar dapat menambah fiskus untuk memaksimalkan pelaksanaan Self Assesment System yang ada di Indonesia sehingga dapat menambah penerimaan PPN..

\section{Daftar Pustaka:}

Adinda Ade, (2017). Ini penyebab PPN 2016 Terkontraksi. [Online]. www.nasional.kontan.co.id/news/ini-penyebab-ppn-2016-terkontraksi. [4 Januari 2017].

Anwar Sanusi, (2010). Metode Penelitian Bisnis, Salemba Empat, Jakarta.

Basuki, Agus Tri and Prawoto, Nano. (2016). Analisis Regresi Dalam Penelitian Ekonomi \& Bisnis : Dilengkapi Aplikasi SPSS \& EVIEWS. Depok: PT Rajagrafindo Persada.

B.llyas, Wirawan dan Richard Burton. (2010). "Hukum Pajak". Jakarta: Salemba Empat.

Djuanda, Gustian dan Irwansyah Lubis. (2011).Pelaporan Pajak Pertambahan Nilai. Edisi Revisi. Elex Media Komputindo. Jakarta..

Egidijus Bikas dan Emili Andrukaite, 2013. Factors Affecting Value Added Tax Revenue.

Hizkia Mulki, (2015). Pengaruh Restitusi PPN dan Ektensifikasi Pajak Terhadap Penerimaan Pajak (Studi Kasus Pada Kantor Pelayanan Pajak Pratama Sumedang Periode 2011-2015). Skripsi, Universitas Komputer Indonesia.

Ida Ayu Ivon Trisnayanti dan Ketut Jati, (2015). Pengaruh Self Assesment System, Pemeriksaan Pajak, pada Penerimaaan Pajak Pertambahan Nilai (PPN). Jurnal Akuntansi ISSN:2302-8556.

Mardiasmo. (2016). Perpajakan. Edisi Revisi 2016, Yogyakarta: Andi.

Melisa LD Sadiq, Srikandi Kumadj, dan Achmad Husaini, (2015). Pengaruh Self Assesment System terhadap Penerimaan Pajak Pertambahan Nilai (Studi pada KPP Pratama Singosari Malang). Jurnal Perpajakan Vol. 7 No. 1.

Oji Sareoji, (2017). Menakar Kadar Kepatuhan Wajib Pajak. [Online] www.pajak.go.id/content/article/menakar-kadar-kepatuhan-wajib-pajak. [1 Maret 2017].

Resmi, siti . (2017. Perpajakan Teori dan Kasus. Buku 1 Edisi Sepuluh. Jakarta. Salemba Empat.

Undang-Undang Nomor 42 Tahun 2009 tentang Pajak Pertambahan Nilai dan Pajak Penjualan atas Barang Mewah.

Sugiyono. (2015). Metode Penelitian Kuantitatif dan Kualitatif dan R\&D. Bandung: Alfabeta

Sujarweni, Wiratna. 2015. SPSS Untuk Penelitian. Yogyakarta : Pustaka Baru Press.

Titian Vegirawati, (2011). Pengaruh Penerbitan Surat Tagihan Pajak dengan Penerimaan Pajak pada KPP Pratama llir Timur Palembang. Jurnal Ekonomi dan Akuntansi Vol. 1 No, 3.

Waluyo .(2011). Perpajakan Indonesia. Jakarta : Salemba Empat. 